\title{
KETERLIBATAN AMERIKA SERIKAT DALAM PENYELESAIAN KONFLIK IRIAN BARAT 1960-1963
}

\author{
Feronika Sryudha Wihardyantie, Wawan Darmawan, Ayi Budi Santosa \\ Departemen Pendidikan Sejarah, Universitas Pendidikan Indonesia \\ fwihardyantie@gmail.com,wawand@upi.edu,ayibud@upi.edu
}

Abstract: In general, the research discusses the conflict in West Irian which involved the United States to help resolve disputes between Indonesia and the Netherlands in 1960-1963. This research was conducted to answer the main question, namely "How was the involvement of the United States in the settlement of the West Irian conflict between Indonesia and the Netherlands 1960-1963?". To answer the formulation of the problem, researchers use historical methods that include heuristics, criticism, interpretation, and historiography. Based on the results of the research, the conflict in West Irian in 1960-1963 was the result of the absence of an agreement between Indonesia and the Netherlands to make peace. Seeing this situation, the United States was interested in helping resolve the conflict. In addition, the United States had interests in the Asian region in order to stem communism, especially in Indonesia and intended to distance Indonesia from its dependence on the Soviet Union. The United States was willing to be a mediator in resolving the West Irian conflict. Mediation was held by holding negotiations between Indonesia and the Netherlands beginning with the Round Table Conference (KMB), Middleburg Negotiations, and the New York Agreement. The settlement of the West Irian conflict with the involvement of the United States influenced the diplomatic relations of the United States with Indonesia and the Netherlands.

Abstrak: $\quad$ Secara umum penelitian membahas mengenai konflik Irian Barat yang meilibatkan Amerika Serikat untuk membantu menyelesaikan pertikaian antara Indonesia dan Belanda pada tahun 1960-1963. Penelitian ini dilakukan untuk menjawab pertanyaan utama yaitu "Bagaimana Keterlibatan Amerika Serikat dalam Penyelesaian Konflik Irian Barat antara Indonesia dan Belanda 1960-1963?” Untuk menjawab rumusan masalah tersebut, peneliti menggunakan metode historis yang meliputi heuristik, kritik, interpretasi dan historiografi. Berdasarkan hasil dari penelitian, konflik Irian Barat pada tahun 1960-1963 akibat tidak menemukan kesepakatan antara Indonesia dan Belanda untuk berdamai. Melihat keadaan itu, Amerika Serikat tertarik untuk membantu menyelesaikan konflik tersebut. Selain itu, Amerika Serikat memiliki kepentingan di kawasan Asia dalam rangka membendung komunis terutama di Indonesia dan Amerika Serikat berniat untuk menjauhkan Indonesia dari ketergantungannya terhadap Uni Soviet. Sehingga Amerika Serikat bersedia untuk menjadi meditor dalam penyelesaian konflik Irian Barat. Mediasi diadakan dengan mengadakan perundingan-perundingan antara Indonesia dan Belanda dengan diawali melalui Konferensi Meja Bundar (KMB), Perundingan Middleburg, dan Perjanjian New York. Penyelesaian konflik Irian Barat dengan terlibatnya Amerika Serikat berpengaruh terhadap hubungan diplomasinya Amerika Serikat dengan Indonesia dan Belanda.

Kata Kunci: $\quad$ Konflik Irian Barat, Konferensi Meja Bundar, Perjanjian New York, Perundingan Middleburg

\section{PENDAHULUAN}

Dari awal kemerdekaan Republik Indonesia 17 Agustus 1945, permasalahan Irian Barat seolah tidak pernah selesai sampai saat ini. Wilayah Irian Barat merupakan wilayah yang memiliki sumber daya alam yang sangat melimpah terutama dalam bidang pertambangan yaitu tembaga dan emas. Perusahaan pertambangan emas dan tembaga yang terkenal di Irian Barat adalah PT Freeport Indonesia (PTFI) yang terletak di Kabupaten Mimika. PT Freeport Indonesia (PTFI) ini memberikan pemasukan pajak terbesar kepada pemerintah Indonesia. Besaran pajak dari PTFI ini sekitar 700-800 Dollar Amerika, devisa yang masuk ke negara sebesar 24 triliun rupiah. Sehingga wilayah Irian Barat menjadi aset bagi Republik Indonesia sebagai sumber pendapatan bagi negara (Elisabeth, 2012, hlm. 22).

Adanya PTFI tidak dapat dipungkiri menimbulkan permasalahan-permasalahan di wilayah Irian Barat. Karena sebagian besar masyarakat di Irian Barat masih mengalami keterbelakangan ekonomi, sosial, budaya, dan politik telah memicu kesenjangan sosial di wilayah Irian Barat. Dari segi ekonomi, orang-orang yang tinggal di wilayah Irian Barat masih jauh dari taraf kehidupan yang layak. PTFI juga tidak banyak mempekerjakan penduduk asli yang tinggal di Irian Barat. Perekonomian di Irian Barat lebih dikuasai oleh orangorang pendatang dari luar Irian Barat.

Permasalahan yang menyangkut penduduk asli Irian Barat adalah masalah sosial. Adanya kesenjangan sosial, menurut data Susenas 2010 persentase penduduk miskin di Irian Barat masih relatif tinggi meskipun sudah dapat dikatakan menurun dari sepuluh tahun kebelakang (Elisabeth, 2012, hlm. 19). Tetapi, ada permasalahan politik yang berkaitan dengan berintegrasinya wilayah Irian Barat ke Republik Indonesia yang menuai pro dan kontra. Bergabungnya Irian Barat banyak para tokoh yang berpengaruh di Irian Barat yang menolak bergabung, namun banyak juga yang ingin bergabung di bawah Republik Indonesia. Ada beberapa hal yang membuat banyaknya pro dan kontra dikalangan para tokoh, sebab adanya perbedaan pandangan, dan latar belakang tujuan yang ingin dicapai.

HISTORIA: Jurnal Pendidik dan Peneliti Sejarah, p-issn:2620-4789 | e-issn:2615-7993 


\section{Feronika Sryudha Wihardyantie, Wawan Darmawan, dan Ayi Budi Santosa \\ Keterlibatan Amerika Serikat dalam Penyelesaian Konflik Irian Barat 1960-1963}

Setelah bergabung dan adanya pembangunanpembangunan yang dilakukan di Irian Barat terjadi pemberontakan oleh Organisasi Papua Merdeka (OPM). Organisasi Papua Merdeka merupakan nama yang diberikan oleh Pemerintah Republik Indonesia kepada setiap organisasi atau fraksi Irian Jaya yang mendukung untuk melepaskan diri dari wilayah Republik Indonesia dan yang ingin memerdekakan diri sebagai sebuah negara. Pemberontakan Organisasi Papua Merdeka dipimpin oleh Sersan Mayor Permenas Ferry Awom mantan anggita Batalyon Sukarelawan Papua yang merupakan bentukan dari Belanda yang berawal di daerah Manokwari. Kemudian OPM terus menjalar ke daerah-daerah yang ada di Irian Barat seperti Fakfak, Sorong, Biak-Numfor, dan sekitarnya. OPM ini lebih kepada merupakan gerakan separatis yang memiliki tujuan untuk menghadang terhadap proses berintegrasinya Irian Barat masuk ke Republik Indonesia (Djopari, 1993, hlm. 100).

Sebab munculnya pemberontakan yang dilakukan oleh OPM salah satunya adalah faktor politik. Dimana pemberontakan OPM diawali dengan janji pemerintah Belanda yang akan mendirikan negara untuk Papua. Namun, janji tersebut tidak dapat direalisasikan karena pada tahun 1962 Irian Barat diserahkan kepada pemerintah Indonesia melalui perjanjian New York. Sebagaimana yang dikutip dari Djopari (1993):

Pemerintahan Belanda menjanjikan pada rakyat Papua untuk mendirikan suatu negara (boneka) Papua yang terlepas dari Republik Indonesia. Janji tersebut tidak dapat direalisasi sebab Irian Jaya harus diserahkan kepada Indonesia melalui perjanjian New York 1962. Walaupun dalam perjanjian itu terdapat pasal tentang hak untuk menentukan nasib sendiri, namun pelaksaannya diserahkan kepada Indonesia dan disaksikan oleh penjabat PBB. (hlm. 105-106)

Keterlibatan Amerika Serikat dalam permasalahan Indonesia sudah terjadi sejak awal kemerdekaan pada tahun 1945 dan kemerdekaan Indonesia pun disambut dengan baik. Selain itu, adanya sambutan yang baik dari Presiden Amerika Serikat masa pemerintahan Harry S. Trauman, dimana dalam pidatonya pada saat menggelar Kongres Amerika Serikat 12 Maret 1947 menyatakan bahwa dukungannya terhadap bangsa-bangsa yang sedang berjuang melawan penindasan dan tekanan dari kaum minoritas yang bersenjata atau tekanan dari luar negeri, pidatonya ini dikenal dengan Doktrin Trauman (Joshua, hlm. 2). Dipertegas lagi secara resmi Amerika Serikat membuka kedutaan besar di Indonesia, begitupun Indonesia membuka kedutaan besar di Amerika Serikat.

Hubungan bilateral antara Amerika Serikat dengan Indonesia didasari oleh mencegahnya penyebaran ideologi komunis yang sedang berkembang di wilayah Eropa Timur dan mulai berkembang di wilayah Asia. Sehingga dari setiap kebijakan presiden yang memimpin Amerika Serikat itu selalu memiliki tujuan yang sama untuk mencegah penyebaran ideologi komunis agar tidak terjadi efek domino di wilayah Asia. Amerika Serikat awalnya memang tidak memiliki kepentingan dan ketertarikan terhadap Indonesia, namun semakin memuncaknya penyebaran ideologi komunis di Asia maka Amerika Serikat mulai tertarik untuk terlibat secara langsung dalam menyelesaikan permasalahan yang sedang Indonesia hadapi. Seperti yang dinyatakan menurut Kahin \& Audrey (1997):

Amerika berusaha membendung penyebaran ideologi komunis menyebar di wilayah Eropa meningkat, tetapi ada wilayah yang harus diperhatikan Amerika juga yaitu wilayah Asia khususnya adalah China. Kekhawatiran Amerika bahwa ideologi komunis yang ada di China menyebar ke wilayah Asia lainnya, termasuk salah satunya adalah Indonesia. Seperti halnya dapat dilihat bahwa pada tahun 1947 ketika perekonomian Belanda dan Prancis membaik bahaya akan penyebaran ideologi komunis semakin berkurang. Tetapi, pada saat itu pula kaum komunis yang ada di China akan menang. (hlm. 34)

Amerika Serikat merupaka negara yang tidak akan pernah ikut terlibat dalam masalah negara lain, jika tidak menguntungkan baginya. Menurutnya jika tidak ikut campur dalam permasalahan Indonesia dalam menghadapi konflik mengenai wilayah Irian Barat akan berdampak terhadap kepentingan Amerika Serikat di kawasan Asia, terutama di Indonesia. Melihat wilayah Irian Barat memiliki potensi sumber daya alam yang melimpah terutama dalam bidang pertambangan. Selain itu, kekhawatiran Amerika Serikat akan Indonesia akibat dari Perang Dingin yang sedang dialami oleh Amerika Serikat dengan Uni Soviet. Amerika Serikat tidak ingin Indonesia terkena efek domino dari negara-negara yang berada di kawasan Asia yang telah memihak terhadap kepada Uni Soviet.

Di bukanya Kedutaan Besar Amerika Serikat di Indonesia dan pemerintah Indonesia membuka Kedutaan Besar di Amerika Serikat, berpengaruh terhadap kebijakan luar negeri Amerika Serikat yang tadinya mendukung pemerintahan Belanda berubah menjadi mendukung pemerintah Indonesia. Akibat dari melihat keadaan di Asia terutama di Indonesia, bahwa Uni Soviet mulai mendekati pemerintah Indonesia dan Amerika Serikat mulai kewalahan. Sehingga kebijakan luar negeri Amerika Serikat berubah terhadap Indonesia terutama pada saat masa pemeritahan Presiden John F Kennedy tahun 1960-an (Zeldie \& McDonough, 2007, hlm. 45). Pada tahun 1960-an Amerika Serikat lebih memfokuskan terhadap bagaimana mengatasi komunis di berbagai wilayah dan negara, salah satunya adalah di kawasan Asia sendiri dikhususkan di wilayah Indonesia.

Amerika Serikat melihat permasalahan-permasalahan yang ada di Indonesia tidak pernah selesai, terutama permasalahan Irian Barat. Pertama sengketa pembebasan Irian Barat dengan Belanda, dan kedua setelah Irian Barat masuk menjadi wilayah bagian dari Republik Indonesia masih menjadi perselisihan. Hal ini membuat Amerika Serikat terlibat langsung dalam penyelesaian Irian Barat. Selain itu, terlibatnya Amerika Serikat di Indonesia memiliki agenda politik tersendiri. Dimana agenda politik yang dirancang oleh Amerika Serikat salah satunya untuk dapat menguasai wilayah Irian Barat yang kaya akan sumber daya alam terutama minyak, emas dan tembaga.

Amerika Serikat memiliki kepentingan ingin menjadikan Indonesia sebagai negara bagian dari Amerika Serikat. Selain

HISTORIA: Jurnal Pendidik dan Peneliti Sejarah, p-issn:2620-4789 | e-issn:2615-7993 
itu yang menjadi alasan ikut terlibat dalam permasalahan Irian Barat adalah peran Presiden Soekarno yang dianggap sebagai Presiden diktator yang menghalangi kepentingan Amerika Serikat (Fukuyama, 2006, hlm. 121). Banyak bantuan yang diberikan oleh Amerika Serikat kepada Indonesia dalam membantu masalah pembebasan Irian Barat seperti biaya dalam pembelian alat-alat militer dan bantuan secara militer yang diberikan (Bradley \& Lubis, 1991, hlm. 173).

Hubungan antara Indonesia dan Amerika Serikat pada tahun 1960-an mengalami perubahan yang lebih baik dibandingkan tahun-tahun sebelumnya. Sikap Amerika Serikat yang mendukung dan memfasilitasi Indonesia dalam merebut Irian Barat dari Belanda tidak terlepas dari kepentingan Amerika Serikat di wilayah Irian Barat yang kaya akan sumber daya alam, yaitu minyak, emas dan tembaga. Dengan adanya PT Freeport Indonesia (PTFI) di Irian Barat yang di pegang oleh Amerika Serikat. Hal ini menjadi bukti bahwa keterlibatan Amerika Serikat di wilayah Irian Barat bukan hanya kepentingan politik untuk membendung penyebaran komunis masuk ke Indonesia agar tidak terjadi efek domino, tetapi ada kepentingan ekonomi yang ingin menguasai wilayah Irian Barat.

Penyelesaian konflik Irian Barat dengan adanya keterlibatan Amerika Serikat dalam membantu menyelesaikan masalah tersebut. Sebab, masalah Irian Barat telah menjadi agenda pembahasan Dewan Keamanan PBB sejak tahun 1949. Namun, selama perundingan-perundingan yang dilakukan oleh pemerintah Indonesia dengan pemerintah Belanda mengenai masalah Irian Barat, pemerintah Belanda selalu mengelak untuk membahas masalah tersebut. Selain itu, hubungan bilateral antara Indoensia dengan Ameirka Serikat dari awal kemerdekaan hubungan diantara keduanya tidak berjalan dengan baik. Terlihat dengan perbedaan sikap Presiden Amerika Serikat yaitu Presiden Eisenhower yang bersikap keras terhadap pemerintahan Indonesia terutama kepada Presiden Soekarno yang menganggap bagian dari golongan kiri. Sedangkan pada masa Presiden John F Kennedy sikap pemerintah Amerika Serikat berbeda jauh dengan Presiden Eisenhower, Presiden John F Kennedy berusaha untuk merangkul dan mendapatkan simpati dari pemerintah Indoensia terutama Presiden Soekarno.

Amerika Serikat bukan hanya untuk menengahi permasalahan sengketa wilayah Irian Barat antara Indonesia dan Belanda, tetapi Amerika Serikat memiliki kepentingan lain di Irian Barat dalam masalah ekonomi. Selain masalah ekonomi, motif Amerika Serikat bersedia membantu dalam penyelesaian konflik Irian Barat, Amerika Serikat menginginkan Irian Barat sesuai dengan keinginan Belanda menjadi sebuah negara yang merdeka. Karena Amerika Serikat dapat mengelola wilayah Irian Barat dengan leluasa tanpa harus mengadakan perundingan dan perjanjian dengan pemerintah Indonesia. Pada tahun 1960 sampai 1963 merupakan klimaks dari penyelesaian masalah Irian Barat antara Indonesia dan Belanda. Selain itu, pada tahun 1960 sampai 1963 telah terjadi perubahan sikap dari Amerika Serikat mengenai kebijakan politik luar negeri Amerika Serikat terhadap Indonesia maupun terhadap Belanda.

\section{METODE}

Penelitian artikel ini menggunakan metode historis yang dikemukakan oleh Gottschalk (1975, hlm. 32) yaitu merupakan proses menguji dan menganalisis secara kritis rekaman dan peninggalan masa lampau. Sedangkan, menurut Abdurrachman Surjomihardjo (1979, hlm. 112) metode historis merupakan proses yang telah dilaksanakan oleh sejarawan dalam usaha mencari, mengumpulkan, menguji, memilih, memisah dan menyajikan fakta sejarah serta tafsirannya dalam susunan yang teratur. Selain itu medote historis atau sejarah menurut Ismaun (2005, hlm. 34) metode sejarah ialah rekonstruksi imajinatif tentang gambaran masa lampau peristiwa-peristiwa sejarah secara kritis dan analisis berdasarkan bukti-bukti dan data peninggalan masa lampau. Metode historis merupakan metode yang digunakan untuk menganalisis dan mengkaji sebuah permasalahan atau peristiwa sejarah untuk memperoleh suatu data yang relevan dan dapat dipertanggung jawabkan. Adapun tahapan penelitian dalam penelitian sejarah menurut Sjamsuddin (2012, hlm. 67-121) yaitu (1) heuristik; (2) kritik; (3) interpretasi; dan (4) historiografi.

Tahapan tersebut dapat berkembang menjadi langkahlangkah yang dapat menunjang penelitian, diantaranya memilih suatu topik yang sesuai, mengusut semua evidensi (bukti) yang revelan dengan topik, membuat catatan tentang itu apa saja yang dianggap penting dan relevan dengan topik yang ditemukan ketika penelitian sedang berlangsung (misalnya dengan menggunakan system cards); sekarang dengan adanya fotokopi, computer, internet menjadi lebih mudah dan system card "ketinggalan jaman", mengevaluasi secara kritis semua evidensi yang telah dikumpulkan (kritik sumber), menyusun hasil-hasil penelitian (catatan fakta-fakta) ke dalam suatu pola yang benar dan berarti yaitu sistematika tertentu yang telah disiapkan sebelumnya, dan menyajikannya dalam suatu cara yang dapat menarik perhatian dan mengkomunikasikannya kepada para pembaca sehingga dapat dimengerti sejelas mungkin.

\section{PEMBAHASAN}

Pada bagian ini peneliti akan menguraikan hasil dari penelitian dan pembahasan peneliti yang telah diperoleh dengan melalui beberapa tahapan dimulai dengan heuristik sampai kepada historiografi. Pada tahun 1960-an terjadi perang dingin antara Amerika Serikat dan Uni Soviet, kedua negara tersebut memiliki ideologi yang berbeda antara liberal dengan komunis. Selain itu, dalam Perang Dingin kedua negara saling berlomba dalam persenjataan. Wilayah Asia merupakan wilayah yang terkena dampak dari Perang Dingin antara Amerika Serikat dan Uni Soviet (Mackie, 2014, hlm. 205).

Untuk memperluas pengaruhnya di Eropa ataupun di Asia pemerintah Amerika Serikat membentuk beberapa organisasi Internasional yang dapat memperkuat perpolitikannya. Di Eropa, Amerika Serikat membentuk Aliansi Pertahanan North Atlantic Treaty Organization (NATO) yang sebelumnya Treaty of Brussels. NATO ini diikuti oleh negera-negara Eropa yaitu 
Belgia, Perancis, Luxemburg, Belanda dan Inggris serta tujuh negara lainnya. Treaty of Brussels awalnya hanya merupakan perjanjian mengenai collective-security, budaya dan sosial. Selain itu, perjanjian collective-security dibentuk setelah penyerangan Uni Soviet ke Czechoslovakia (Barany, 2009, hlm. 108).

Sedangkan di Asia sendiri Amerika Serikat membentuk Southeast Asia Trearty Organization (SEATO) sebagai bentuk reaksi pemerintah Amerika Serikat terhadap krisis yang terjadi di Asia Tenggara. Selain itu, pembentukan SEATO di Asia Tenggara bertujuan untuk pembendungan komunis di Asia Tenggara (Modelski, 2015, hlm. 27-28). Melihat keadaan di Asia, pemerintah Amerika Serikat melibatkan diri dalam membantu menyelesaikan bermacam permasalahan yang ada di Asia. Hal tersebut dilakukan untuk menjaga kepentingan nasional Amerika Serikat di Asia, baik kepentingan politik maupun ekonomi. Tindakan-tindakan Amerika Serikat dalam keterlibatannya menyelesaikan permasalahan yang ada di Asia dengan ikut terlibat dalam Perang Korea, Perang Vietnam meskipun mengalami kekalahan, dan membantu pemerintah Indonesia dalam menyelesaikan konflik Irian Barat dengan Belanda.

Konflik antara Indonesia dan Belanda mendapatkan perhatian dari Dewan Keamanan PBB, Amerika Serikat dan negara-negara Eropa lainnya. Sebab, konflik antara Indonesia dan Belanda mengenai status wilayah Irian Barat telah berlangsung dari tahun 1949 setelah dilaksanakannya Konferensi Meja Bundar (KMB) yang di dalamnya termuat bahwa mengenai masalah Irian Barat setahun kemudian akan diselesaikan oleh pemerintah Indonesia dan pemerintah Belanda. Namun, pada kenyataannya pemerintah Belanda masih mempertahankan Irian Barat dengan berbagai macam alasan, diantaranya mengenai pembangunan wilayah Irian Barat yang akan memakan biaya yang besar, selain itu antara rakyat Indonesia dengan penduduk Irian Barat tidak memiliki persamaan, terutama akan kesadaran historis dengan rakyat Indonesia.

Konflik Irian Barat telah menjadi isu internasional yang diperbincangkan di PBB, banyak negara-negara yang memusatkan perhatiannya kepada masalah Irian Barat, salah satunya Amerika Serikat. Tahun 1960-an di Amerika Serikat terpilih Presiden Amerika Serikat baru yaitu Presiden John F Kennedy dengan kebijakan politik luar negeri yang tidak jauh dari presiden-presiden sebelumnya yang ingin membendung ideologi komunis berkembang di dunia. Terutama di Asia setelah Perang Vietnam dan Perang Korea, pemerintah Amerika Serikat tidak ingin ada lagi negara lain yang menjadi bagian dari komunis. Melihat keadaan Indonesia dan Belanda yang tak kunjung selesai membuat Amerika Serikat turun langsung turut menyelesaikan permasalahan Irian Barat. Selain itu, Amerika Serikat tidak ingin Indonesia terus bergantung kepada pemerintah Uni Soviet, salah satu contohnya adalah Uni Soviet memberikan bantuan ekonomi dan persenjataan kepada pemerintah Indonesia. Hal tersebut membuat Amerika Serikat harus turun tangan untuk membantu menyelesaikan konflik Irian Barat antara Indonesia dan Belanda.

Pemerintah Amerika Serikat di bawah pemerintahan Presiden John F Kennedy menyatakan bersedia akan HISTORIA: Jurnal Pendidik dan Peneliti Sejarah, p-issn:2620-4789 | e-issn:2615-7993 membantu Indonesia dan Belanda dalam menyelesaikan konflik Irian Barat dengan jalan diplomasi secara damai. Hal itu dilakukan selain mengenai pembendungan komunis, pemerintah Amerika Serikat membantu menyelesaikan konflik Irian Barat untuk menghindari terjadinya perang terbuka antara Indonesia dan Belanda. Pemerintah Amerika Serikat mengirimkan perwakilannya untuk menjadi mediator bagi Indonesia dan Belanda yaitu Elssworth Bunker. Sehingga diadakan beberapa perundingan untuk menyelesaikan konflik tersebut diantaranya ada perundingan Middleburg dan disetujuinya dengan Perjanjian New York.

Sebelum adanya kedua perundingan dan perjanjian tersebut, Indonesia dan Belanda masih mempertahankan pendapatnya masing-masing. Pemerintah Indonesia menginginkan sesegera mungkin untuk dilaksanakannya perundingan dan penyerahan wilayah Irian Barat ke NKRI, tetapi pemerintah Belanda masih mempertahankan Irian Barat dengan menginginkan diadakannya penentuan nasib sendiri bagi rakyat Irian Barat, baru setelah itu diadakan penyerahan kekuasaan kepada pemerintah Indonesia jika rakyat Irian Barat menginginkan berinstegrasi dengan Indonesia. Perundingan yang dilakukan oleh pemerintah Indonesia dan pemerintah Belanda masih berlangsung dan belum menyampai titik temu untuk berdamai sehingga ditunda untuk sementara.

Akhirnya, pemerintah Indonesia mengirimkan pasukan militer ke Irian Barat di Pulau Aru, mereka telah siap siaga untuk menggempur pasukan tentara Belanda di Irian Barat jika penyerahan Irian Barat ditunda kembali. Tekanan dan intervensi yang keras terus diberikan oleh pemerintah Amerika Serikat kepada pemerintah Belanda untuk bersedia berunding dengan pemerintah Indonesia. Sehingga, pemerintah Belanda dan pemerintah Indonesia bersedia berunding kembali dengan beberapa syarat yang diberikan kepada pihak pemerintah Amerika Serikat yang diwakili oleh Elssworth Bunker sebagai mediator. Syarat-syarat yang telah diajukan oleh kedua belah pihak disetujui oleh Elssworth Bunker, sehingga menjadi sebuah rancangan kesepakatan untuk Indonesia dan Belanda yang langsung diajukan kepada Presiden John F Kennedy dan mendapatkan persetujuan dari Presiden John F Kennedy untuk menjadi keputusan bagi kedua pemerintah Indonesia dan Belanda.

Perundingan antara pemerintah Indonesia dan pemerintah Belanda dilakukan secara rahasia di Kota Middleburg, Virginia yang tidak jauh dari Washington, DC pada tanggal 20 Maret 1962 (Wardaya, 2008, hlm. 258). Perundingan tersebut menghasilkan dua kesepakatan yaitu (1) harus ada pemerintah sementara di Irian Barat; dan (2) setuju menghormati hak azasi rakyat Irian Barat. Namun, ada perbedaan mengenai hak azasi rakyat Irian Barat antara Indonesia dan Belanda. Menurut Indonesia adanya pemerintahan sementara di Irian Barat merupakan peralihan dari pemerintah Belanda ke Pemerintah Indonesia. Tetapi, pihak Belanda berpendapat bahwa dengan adanya pemerintah sementara di Irian Barat tidak dapat menyerahkan Irian Barat kepada Indonesia, karena tidak mempertimbangkan hak azasi rakyat Irian Barat (Subandrio, 2001, hlm. 55).

Melihat hal ini, para pejabat Amerika Serikat salah satunya adalah Elssworth Bunker di Washington merumuskan 
sebuah formula dengan tujuan sebagai landasan bagi Indonesia dan Belanda untuk menyelesiakan permasalahan Irian Barat. Sehingga pada tangga 29 Maret 1962 pihak Amerika Serikat mengirimkan sebuah usulan kompromi kepada Belanda dan Indonesia yang dikenal dengan Usulan Bunker, diantaranya (Wardaya, 2008, hlm. 258-259):

(1) Suatu transfer Irian Barat kepada Dewan Keamanan PBB, yang setahun kemudian akan diikuti oleh;

(2) transfer wilayah tersebut kepada Indonesia, yang;

(3) kemudian akan memberikan kesempatan untuk memilih apakah hendak merdeka atau menjadi bagian dari Indonesia.

Formula Bunker atau yang dikenal rencana Bunker diterima oleh pemerintah Indonesia, akan tetapi pemerintah Belanda menolak rencana Bunker. Sebab, menurut pandangan pemerintah Belanda dalam rencana Bunker lebih menguntungkan pihak pemerintah Indonesia, sedangkan bagi pemerintah Belanda tidak mendapatkan kejelasan mengenai waktu penentuan nasib sendiri bagi rakyat Irian Barat. Namun, Sekretaris Jenderal PBB, U Thant mengirimkan pesan melalui telegram menegaskan kepada kedua belah pihak untuk menerima rencana Bunker. Rencana Bunker merupakan suatu langkah yang tepat dalam menyelesaikan permasalahan Irian Barat, sebab dalam satu formula atau rancangan keinginan kedua belah pihak dapat diselesaikan.

Sehingga pada tanggal 1 Agustus 1962 terumuskan hasil perundingan yang disetujui oleh para delegasi pemerintah Indonesia dan pemerintah Belanda. Isi dari hasil perundingan di Middleburg dinamakan "Kesepakatan Awal" untuk menyelesaikan perselisihan diantara Indonesia dan Belanda mengenai masalah Irian Barat, diantaranya berisikan (Wardya, 2008, hlm. 263-264):

1. Segera setelah Resolusi Majelis Umum PBB dikeluarkan, pemerintah Belanda akan mengalihkan pemerintahan kepada United Nation Temporary Executive Author (UNTEA) otoritas eksekutif PBB;

2. Otoritas eksekutif sementara ini akan menentukan dimulainya proses peralihan pemerintah kepada Indonesia sewaktu-waktu setelah Mei 1963;

3. Pasukan Indonesia di Irian Barat akan berada di bawah kendali UNTEA;

4. UNTEA boleh mendayagunakan para pejabat Belanda dan Indonesia;

5. Satu tahun sebelum "penentuan pendapat rakyat" yang mesti dilaksanakan sebelum 1969, Sekretaris Jenderal PBB akan menunjuk wakilnya dan staf untuk menasihati dan membantunya dalam pelaksanaan tugas-tugasnya;

6. Bendera Indonesia boleh dikibarkan di samping bendera PBB mulai Januari 1963.

Keputusan awal dapat diterima oleh kedua belah pihak Indonesia dan Belanda yang nantinya akan mengadakan perundingan dan penandatanganan kesepakatan secara resmi. Pemerintah Belanda akhirnya menyetujui dengan diadakanya keputusan awal mengenai pembahasan masalah Irian Barat yang selanjutkan akan dilanjutkan dalam perundingan secara resmi oleh pemerintah Indonesia dan pemerintah Belanda dengan dimediatori oleh pemerintah Amerika Serikat. Pada tanggal 15 Agustus 1962 akhirnya menjadi akhir diplomasi antara Indonesia dan Belanda mengenai konflik Irian Barat, dengan ditandatanganinya perjanjian yang dilaksanakan di markas besar PBB di New York, sehingga terkenal dengan Perjanjian New York sebagai akhir dari konflik Irian Barat.

Terlibatnya Amerika Serikat dalam meneyelesaikan konflik Irian Barat berhasil dilakukan oleh Amerika Serikat di bawah pemerintahan Presiden John F Kennedy. Sehingga, berdampak terhadap pemerintah Indonesia dan pemerintah Belanda, serta kepada pemerintah Amerika Serikat juga. Bagi pemerintah Indonesia dengan kembalinya Irian Barat ke NKRI, pemerintah Indonesia akhirnya mencapai tujuan akhir mereka mengenai konflik Irian Barat. Selain itu, dengan sumber daya alam yang melimpah di Irian Barat memberikan keuntungan bagi pemerintah Indonesia. Tetapi, pemerintah di Indonesia mengalami masalah dengan penduduk Irian Barat yang mengeluarkan pernyataannya "Papua Merdeka" yang digembor-gemborkan oleh kelompok yang mendukung Belanda yang ingin Irian Barat menjadi sebuah negara yang berdaulat. Adanya kelompok yang menentang untuk berintegrasi dengan Indonesia menjadi ancaman bagi pemerintah Indonesia.

Selain itu, ada banyak penindasan yang dilakukan oleh oknum-oknum militer Indonesia yang tinggal di Irian Barat yang seharusnya melindungi dan mengamankan Irian Barat. Hal tersebut memicu adanya gerakan separatis di Irian Barat yang mengancam disintegrasi NKRI. Hubungan antara Indonesia dan Amerika Serikat mulai membaik, pemerintahan Presiden John F Kennedy memanfaatkan situasi konflik Irian Barat untuk menjalin hubungan diplomasi yang lebih erat dengan pemerintah Indonesia. Pemerintah Amerika Serikat memberikan bantuan terhadapa Indonesia untuk dana pembangunan di Indonesia, terutama di Irian Barat.

Dampak bagi Belanda, pemerintah Belanda kecewa terhadap sikap Amerika Serikat yang diharapkan dapat mendukung pemerintahan Belanda mengenai penentuan nasib sendiri bagi rakyat Irian Barat. Pemerintah Belanda kecewa atas tindakan pemerintah Amerika Serikat yang lebih mendukung Indonesia terutama dalam rencana Bunker. Selain itu, pemerintah Belanda menelan kerugian yang telah mereka investasikan dana lebih dari satu milyar gulden untuk mendidik dan mempersiapkan rakyat Papua untuk melaksanakan penentuan nasib sendiri (Poulgrain, 2017, hlm. 224). Permasalahan lain yang harus dihadapi oleh pemerintah Belanda mengenai kepulangan orang-orang Belanda yang ada di Papua dipercepat dari jadwal yang telah ditentukan sebelumnya. Sehingga pada tanggal 1 Mei 1963 Belanda secara resmi meninggalkan Papua dan menyerahkan kepada Indonesia. Kepergian Belanda dari Papua yang lebih cepat meninggalkan kerugian bagi pemerintah Belanda yang telah bekerja keras untuk mencari letak tambang emas yang dapat menguntungkan bagi pemerintahan Belanda di negeri Belanda (Poulgrain, 2017, hlm. 241-242).

Penentuan nasib sendiri untuk rakyat Irian Barat ditunda sampai tahun 1969. Pemerintah Belanda masih berharap penetuan nasib sendiri bagi rakyat Irian Barat dapat memberikan peluang kepada Belanda sesuai dengan rencana 
pemerintah Belanda yang telah dipersiapkan. Tetapi, pada tahun 1969 saat diselenggarkannya Act of Free Choice atau penentuan nasib sendiri rakyat Irian Barat telah bersepakat untuk bersatu dan berintegrasi dengan Negara Kesatuan Republik Indonesia. Meskipun, ada kelompok yang menentang berintegrasi dengan Indonesia dan lebih mendukung pemerintah Belanda yang menjanjikan kemerdekaa bagi rakyat Irian Barat.

\section{SIMPULAN}

Konflik Irian Barat antara Indonesia dan Belanda yang telah menjadi perbincangan di dunia akhirnya membuat Amerika Serikat turun langsung untuk menyelesaikan permasalahan Irian Barat. Selain itu, pada tahun 1960-an sedang berlangsung Perang Dingin antara Amerika Serikat dengan Uni Soviet, salah satunya peperangan mengenai ideologi. Melihat keadaan di Asia dimana komunis sudah menyebar ke beberapa negara di Asia. Amerika Serikat mulai khawatir dengan posisi Indonesia, dengan sudah mulai berkembangnya komunis di Indonesia. Sehingga dalam masalah Irian Barat, Amerika Serikat memanfaatkan situasi tersebut untuk membantu dan ikut terlibat dalam konflik Indonesia dengan Belanda, meskipun akan beresiko terhadap hubungannya dengan Belanda.

Amerika Serikat memainkan peran dalam penyelesaian konflik Irian Barat dengan jalan diplomasi. Pemerintah Amerika Serikat mengirimkan perwakilannya yaitu Elssworth Bunker yang dipercaya untuk menjadi mediator bagi Indonesia dan Belanda. Sehingga, dilaksanakan perundingan Middleburg yang dilakukan secara rahasia untuk mencapai kesepakata berdamai antara Indonesia dan Belanda, yang pada akhirnya menghasilkan sebuah kesepakatan yang disebut sebagai "Rencana Bunker". Perundingan Middleburg menjadi langkah awal untuk melanjutkan perundingan selanjutnya yang akan dilakukan oleh pemerintah Indonesia dan pemerintah Belanda yang akan dilaksanakan di markas besar PBB di New York. Sehingga, perundingan selanjutnya menghasilkan keputusan untuk menyerahkan Irian Barat kepada pemerintah Indonesia dari pemerintah Belanda melalui pemerintahan sementara UNTEA di Irian Barat, serta ditandatanganinya sebuah perjanjian antara Indonesia dan Belanda di bawah pengawasan Dewan Keamanan PBB dan pemerintah Amerika Serikat. Perjanjian tersebut dikenal dengan Perjanjian New York yang ditandatangani pada tanggal 15 Agustus 1962.

Terlibatnya Amerika Serikat dalam penyelesaian konflik Irian Barat berpengaruh terhadap hubungannya dengan Indonesia maupun Belanda, ataupun berdampak terhadap Indonesia dan Belanda setelah Irian Barat menjadi bagian dari NKRI. Hubungan antara Indonesia dengan Amerika Serikat semakin membaik dalam menjalankan hubungan diplomasi. Selain itu, pemerintah Amerika Serikat memberikan bantuan ekonomi kepada pemerintah Indonesia dalam rangka membangun Irian Barat. Namun, hubungan diplomasi antara Amerika Serikat dengan Belanda mulai tidak berjalan dengan baik, setelah penyerahan Irian Barat menjadi bagian NKRI. Pemerintah Belanda mengalami kekecewaan terhadap pemerintah Amerika Serikat, namun hal tersebut harus ditelan oleh pemerintah Belanda sebagai resiko dari sekutunya Amerika Serikat. Bagi pemeritah Indonesia kembalinya Irian Barat menjadi bagian dari NKRI merupakan akhir dari perjuangan rakyat Indonesia melawan Belanda dan merebut wilayah Irian Barat dari Belanda. Namun, bagi pemerintah Belanda kembalinya Irian Barart menjadi bagian NKRI merupakan hal yang sangat mengecewakan melihat bahwa pemerintah Belanda telah mengeluarkan biaya yang tidak sedikit untuk memulai pembangunan di Irian Barat.

\section{REFERENSI}

Barany, Zoltan. (2009). NATO at Sixty. Journal of Democracy, 2(20), 108-122.

Bradley, William L., \& Lubis, Mochtar. (1991). DokumenDokumen Pilihan Tentang Politik Luar Negeri Amerika Serikat dan Asia. Jakarta: Yayasan Obor Indonesia.

Djafar, Z. (2012). “Kemerdekaan Papua dan Relevansi Reaksi Tiga Negara”. Jurnal Penelitian Politik, 9(1), 103-104.

Djopari, John R.G. (1993). Pemberontakan Organisasi Papua Merdeka. Jakarta: Gramedia.

Elisabeth, Adriana. (2012). "Perdamaian dan Pembangunan Papua: Problematika Politik Atau Ekonomi?”. Jurnal Penelitian Politik, 9(1), 22.

Fukuyama, Francis. (2006). America at The Crossroads: Democracy, Power, and The Neoconservative Legacy. New Haven: Yale University Press.

Gottschalk, L. (1985). Mengerti Sejarah. Jakarta: Universitas Indonesia Press.

Ismaun. (2005). Sejarah Sebagai Ilmu dan Wahana Pendidikan. Bandung: Tim Kreatif Jurusan Pendidikan Sejarah UPI.

Joshua, N. (Tanpa Tahun). Amerika Serikat dan Indonesia dalam Masalah Pembebasan Papua Barat". Diakses dari http://www.academia.edu/3509315/Amerika_Serikat_ dan_Masala_Pembebasan_Irian_Barat_1947-1962

Kahin, G. \& Kahin, A.R. (1997). Subversi Sebagai Politik Luar Negeri Menyikapi Keterlibatan CIA di Indonesia. Jakarta: Pustaka Utama Grafiti.

Mackie. J. (2014). United States Interest In Southeast Asia. Australia Outlook, 32(2), 205.

Modelski, J.A. (2015). Indo-China and SEATO. Australia Outlook, 13(1), 27-28.

Poulgrain, Greg. (2017). Bayang-Bayang Intervensi Perang Siasat John F Kennedy dan Allen Dulles atas Sukarno. Yogyakarta: Best Publisher.

Sjamsuddin, Helius. (2012). Metodologi Sejarah. Yogyakara: Ombak.

Subandrio. (2001). Meluruskan Sejarah Perjuangan Irian Barat. Jakarta: Yayasan Kepada Bangsaku.

Surjomihardjo, A. (1979). Pembinaan Bangsa dan Masalah Historiografi. Jakarta: Yayasan Idayu.

Wardaya, Baskara T. (2008). Indonesia Melawan Amerika Konflik Perang Dingin, 1953-1963. Yogyakarta: Galang Press.

Zeldie, Y. \& McDonough. (2007). Siapakah John F Kennedy?. Jakarta: Grasindo.

HISTORIA: Jurnal Pendidik dan Peneliti Sejarah, p-issn:2620-4789 | e-issn:2615-7993 